\title{
Interfollicular Fibrosis in the Thyroid of the Harbour Porpoise: An Endocrine Disruption?
}

\author{
Krishna Das, ${ }^{1,6}$ Arndt Vossen, ${ }^{1}$ Kristal Tolley, ${ }^{2}$ Gisli Víkingsson, ${ }^{3}$ Kristina Thron, ${ }^{4}$ Gundi Müller, ${ }^{5}$ \\ Wolfgang Baumgärtner, ${ }^{5}$ Ursula Siebert ${ }^{1}$ \\ ${ }^{1}$ Research- and Technology Centre Westcoast, Christian-Albrechts-University Kiel, Büsum, Germany \\ ${ }^{2}$ Leslie Hill Molecular Systematics Laboratory, Kirstenbosch Research Centre, South African National Biodiversity Institute, Private Bag X7, Claremont \\ 7735, South Africa \\ ${ }^{3}$ Marine Research Institute, Reykjavík, Iceland \\ ${ }^{4}$ Baltic Sea Research Institute Warnemuende, Warnemuende, Germany \\ ${ }^{5}$ School of Veterinary Medicine Hannover, Hannover, Germany \\ ${ }^{6}$ Mare Center, Laboratory for Oceanology B6c, Liège University, Liège, Belgium
}

Received: 21 April 2005 /Accepted: 19 September 2005

\begin{abstract}
Previous studies have described high levels of polychlorobiphenyls (PCB), polybrominated diphenylether (PBDE), toxaphene, $\quad p, p^{\prime}$-dichlorodiphenyltrichloroethane (DDT), and $p, p^{\prime}$-dichlorodiphenyldichloroethylene (DDE) in the blubber of the harbour porpoise from the North Sea raising the question of a potential endocrine disruption in this species. In the present study, the thyroids of 57 harbour porpoises from the German and Danish (North and Baltic Seas), Norwegian, and Icelandic coasts have been collected for histological and immunohistological investigations. The number of follicles and the relative distribution of follicles, connective, and solid tissues $(\%)$ were quantified in the thyroid of each individual. Then, the potential relationship between the thyroid morphometry data and previously described organic compounds (namely, PCB, PBDE, toxaphene, DDT, and DDE) was investigated using factor analysis and multiple regressions. Thyroid morphology differed strongly between sampling sites. Porpoises from the German (North and Baltic Seas) and Norwegian coasts displayed a high percentage of connective tissues between 30 and $38 \%$ revealing severe interfollicular fibrosis and a high number of large follicles (diameter $>200 \mu \mathrm{m}$ ). A correlation-based principal component analysis (PCA) revealed two principal components explaining $85.9 \%$ of the total variance. The variables PCB, PBDE, DDT, and DDE compounds loaded highest on PC1 whereas toxaphene compound loaded most on PC2. Our results pointed out a relationship between PC1 (PCBs, PBDE, DDE, and DDT compounds) and interfollicular fibrosis in the harbour porpoise thyroids. Such an association is not alone sufficient for a cause-effect relationship but supports the hypothesis of a contaminant-induced thyroid fibrosis in harbour porpoises raising the question of the longterm viability in highly polluted areas.
\end{abstract}

Correspondence to: K. Das; email: Krishna.das@ulg.ac.be
The harbour porpoise (Phocoena phocoena) is the most common cetacean species in the North and Baltic Seas (Hammond et al. 2002). Beside substantial incidental catches, competition with fishery, noise disturbance, and chemical pollutants are likely to contribute to its decrease in recent years (Benke $e t$ al. 1998; Hammond et al. 2002; Read 2002).

The harbour porpoise as a predator may accumulate high concentrations of persistent inorganic and organic pollutants in its tissue (Aguilar and Borrell 1995; Das et al. 2003; Reijnders and Aguilar 2002). Organohalogens are industrial chemicals, by-products of the chemical industry, or pesticides, and may exert toxic effects on wild and laboratory organisms (Wright and Welbourn 2002). Organohalogens such as toxaphene, polybrominated diphenylether (PBDE), polychlorinated biphenyls (PCB), dichlorodiphenyltrichloroethane (DDT), and dichlorodiphenyldichloroethylene (DDE) compounds are strongly suspected to have endocrine-disrupting effects on several fish and mammal species (Aguilar and Borrell 1995; Bruhn et al. 1995; Brouwer et al. 1999; Gregory and Cyr 2002; Wright and Welbourn 2002).

Many pathological lesions have previously been reported in marine mammal species that have been exposed to contaminants with known endocrine-disruptive properties (Gregory and Cyr 2002). Beside reproduction effects, severe adrenocortical hyperplasia, thymic atrophy, splenic depletion, osteoporosis, intestinal ulcers, claw malformations, arteriosclerosis, uterine cell tumors, and decreased epidermal thickness have been reported in grey and ringed seals from the polluted Baltic Sea (Bergman 1999; Bergman and Olsson 1985; Bergman et al. 2002). Few environmental and laboratory researchers have focused on the disruption of the thyroid system, despite the fact that many wildlife species in the world suffer unusual thyroid gland development and ratios of circulating thyroid hormones (THs) (Colborn 2002). Thyroid hormones are important regulators of intermediary metabolism, growth, neural development, and aspects of reproduction (Gregory and Cyr 2002; Sher et al. 1998). In 
cetaceans and other mammals, these hormones are also believed to play an important role in controlling heat loss (McNabb 1992).

Organohalogen compounds such as PCBs and PBDE interact with thyroid hormone expression principally triiodothyronine T3 and thyroxine T4 in fish, rats, and seals (Brouwer et al. 1989, 1999; Braathen et al. 2004; Hall et al. 1998, 2003; Woldstad and Jensen 1999; Zhou et al. 2000; Debier et al. 2005). Because of structural similarities, PCBs congeners (and their hydroxylated metabolites) and thyroid hormones compete for the same binding sites on transport proteins such as transthyretin (TTR) (Brouwer et al. 1989, 1998). Impairment of thyroid functions such as a decrease of thyroid levels, colloid depletion of thyroid follicles, and fibrosis were previously associated with PCB contamination in harbour seals (Brouwer et al. 1989; Schumacher et al. 1993). Evaluation of the thyroid gland morphology may, therefore, be a suitable indicator for compounds that interfere in thyroid hormone metabolism (Brouwer et al. 1999; Schumacher et al. 1993).

The level of organohalogen compounds in the blubber of marine mammals depends upon the species, metabolism, body condition, sex, age, diet, and geographical area (Jepson et al. 1999, 2005; O'Hara and Becker 2003; O'Shea and Tanabe 2003). High levels of PBDE, DDT, and PCBs were previously described in porpoises from the North and Baltic Seas compared to northern coasts of Norway, Iceland, and Greenland (Bruhn et al. 1999; Kleivane et al. 1995; Siebert et al. 2002; Thron et al. 2004). The question arises about the potential endocrine disrupter effect in these porpoises encountering high levels of organic contaminants.

To investigate possible associations between chronic exposition to organic pollutants and thyroid function in harbour porpoises, the structure of thyroid glands of 57 harbour porpoises from German and Danish, Norwegian, and Icelandic waters was examined. The different compartments of the thyroid gland (follicle, connective, and solid tissues) were quantified by histomorphometric and immunohistological analysis and their relative proportion was related to previously described toxaphene, PCB, DDT, DDE, and PBDE compounds (Bruhn et al. 1999; Thron et al. 2004; Siebert et al. 2002).

\section{Materials and Methods}

\section{Tissue Sampling}

Between 1998 and 2001, tissue samples (thyroid, blubber) were collected on 17 porpoises from the German and Danish Baltic Sea, 14 from the German North Sea, 12 from Icelandic, and 14 from Norwegian waters (Fig. 1). Post-mortem investigations were performed according to standard protocol (Siebert et al. 2001). Of the 57 investigated animals, 19 were males and 38 females. Forty-five harbour porpoises were caught animals and 12 porpoises were stranded. The age was determined by counting the dental growth layers (Lockyer 1995).

\section{Histology and Immunohistochemistry}

Samples of the thyroid glands were fixed in $10 \%$ formalin and embedded in paraffin wax at $60^{\circ} \mathrm{C}$ for histological and immunohis- tological investigations. Paraffin wax-embedded tissue sections $(5 \mu \mathrm{m})$ were stained with hematoxylin and eosin (HE) and by elastic van Gieson for the detection of collagen.

For immunohistochemistry, a polyclonal rabbit anti-human thyroglobulin antibody (Code No A 0251, DAKO Corporation) and the Avidin-Biotin-Peroxidase complex method was used as described previously (Baumgärtner et al. 1989). The serum used was from a goat (PAA Laboratories $\mathrm{GmbH}$ ). A monoclonal antibody against the T-cell surface antigen of chicken lymphocytes (T1) was used as a control. The polyclonal antibody against thyroglobulin was used in a solution of 1:2600 (in TBSc). A biotinylated anti-rabbit-immunoglobulin (Vector Laboratories Inc., BA 1000) was used as a secondary antibody. The sections were then treated with avidin-biotin-peroxidase complex (ABC) (Vector Laboratories Inc., PK 4000). As a positive control, thyroid gland sections were treated with the control antibody. Furthermore, previously positively stained sections were used as a control.

\section{Scoring of the Thyroid Gland}

For semiquantitative evaluation, ten randomly selected visual fields in the microscope with a magnification of 200 of each section were observed. The tissue proportion of the thyroid gland was determined. The proportion of the follicle, solid, and elastic connective tissue was estimated and divided into 5 categories $(0-5 \%, 5-25 \%, 25-50 \%$, $50-75 \%, 75-100 \%)$. For each tissue type, a mean value was assigned (Table 1). The calculation of the median used for statistical analyses was performed from 10 values per individual.

\section{Diameter of Thyroid Gland Follicles}

Size and quantity of the thyroid gland follicles were registered. Five images, at microscope magnification of 48 (ocular), were taken of each thyroid slide (Van Giesson coloration). Furthermore, the number of follicles with a diameter smaller than $3 \mathrm{~mm}$ (small follicles; real diameter $<62.5 \mu \mathrm{m}$ ), between 3 and $10 \mathrm{~mm}$ (medium size follicles; real diameter: between 62.5 and $208 \mu \mathrm{m}$ ), and larger than $10 \mathrm{~mm}$ (large size follicles, real diameter $>208 \mu \mathrm{m}$ ) were determined.

\section{PCBs, PBDEs, Toxaphene, DDT, and DDE Analyses}

The blubber concentrations of 6 individual polychlorinated biphenyl (PCB) congeners, 5 individual polybrominated diphenylether (PBDE) congeners, 5 toxaphene congeners, $p, p^{\prime}$-dichlorodiphenyltrichloroethane (DDT), and $p, p^{\prime}$-dichlorodiphenyldichloroethylene (DDE) were measured using standardized methods (Bruhn et al. 1999; Thron et al. 2004). Detailed method and results are presented elsewhere (Bruhn et al. 1999; Siebert et al. 2002; Thron et al. 2004). Briefly, after lipid Soxhlet extraction, blubber samples were analyzed for PCBs, PBDEs, toxaphene, $p, p^{\prime}$-DDT, and $p, p^{\prime}$-DDE. The levels of 5 individual PBDE congeners (IUPAC nos. 47, 99, 100, 153, 154) were determined by GC/MS-EI. The levels of 5 individual toxaphene congeners (Parlar nos. 26, 40, 42, 44, 50) were determined by GC/MSNCI. PCB concentrations correspond to the sum of 6 congeners (nos. $99,149,138,153,180,187)$. All data are expressed in $\mathrm{ng} \mathrm{g}^{-1}$ of lipid.

\section{Statistical Analyses}

The statistical analysis of the data was performed with the statistical program package SPSS 11.5.0. Contaminant values were log-transformed to achieve homogeneity of variances and normal distribution. 


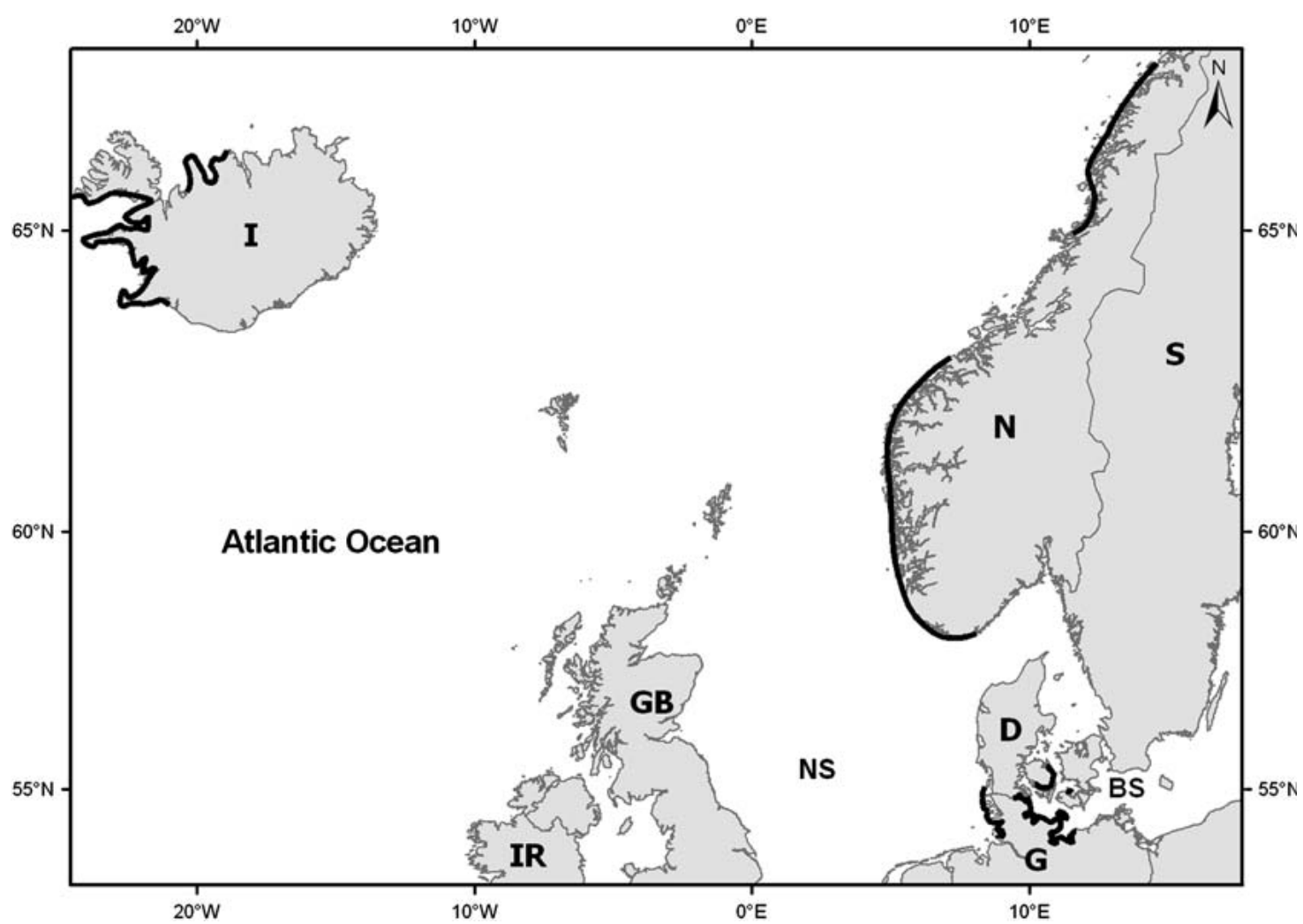

Fig. 1. Harbour porpoise sampling sites within the northeast Atlantic. G: Germany; D: Denmark; S: Sweden; N: Norway; GB: Great Britain; IR: Ireland; I: Iceland; NS: North Sea; BS: Baltic Sea

Table 1. Proportion of the solid, follicle, and connective tissue of the harbour porpoise thyroid observed by microscopy and their related assigned statistical value (in \%)

\begin{tabular}{lc}
\hline Proportion of the thyroid tissue & Assigned value \\
\hline $0-5$ & 2.5 \\
$6-25$ & 15 \\
$26-50$ & 37.5 \\
$51-75$ & 62.5 \\
\hline
\end{tabular}

Thyroid tissue compartments (solid, follicles, and connective tissues) were standardized such that their sum equaled one. The number of follicles (small, middle size, and large diameter) were added to a constant (one) and subsequently log-transformed.

The relationships between thyroid tissue distribution and toxicological data were analyzed in two steps. First, a correlation-based principal component analysis (PCA) was performed to reduce the 5 original pollutant variables in order to avoid misleading results due to correlating independent variables ("multi-collinearity") in subsequent analyses. After the transformation, none of the distributions differed significantly from normality (one-sample Kolmogorov-Smirnov test: all $n \geq 52$, all $p \geq 0.1$; no alpha-level adjustment applied). The PCA was indicated because a considerable proportion of the correlations between the transformed variables was rather large (seven out of ten correlation coefficients larger than 0.5 ) and, correspondingly, justified by a Kaiser-Meyer-Olkin measure of sampling adequacy equaling 0.606 (which is above the required value of 0.5) as well as Bartlett's Test of Sphericity revealing significance (chi-squared $=201$, d.f. $=10, p<0.001$; McGregor 1992). Thereafter, multiple linear regressions were applied with the two factor scores revealed by the PCA and age as the independent variables and thyroid tissue proportion (follicles and connective tissues) or numbers of follicles as the dependent variable. Thus, we calculated a total of five multiple regressions, one for each of the five dependent variables, separately. Solid tissue was excluded from the multiple regression because its proportion exhibited a strong negative correlation with elastic tissue (Pearson correlation: $r_{\mathrm{P}}=-0.86, n=58, p<0.001$ ), meaning that one of the two variables could explain the other. It must be quoted that this global approach combining all the studied compounds was preferred because the pollutants act as a mixture with synergic and antagonistic behaviour.

The bi-plot (see Fig. 5) is based on Pearson's correlation coefficients between percentages of tissues as well as numbers of small, medium, and large follicles, on the one hand, and principal components, on the other hand (Gabriel 1971). In order to reduce the degree of skewness in the distributions of these variables, we arcsine transformed solid and connective tissue percentages and arcsine transformed the square root of follicular tissue percentage. However, these transformations were not sufficient with regard to revealing normally distributed data. Hence, parametric and nonparametric correlations were both calculated. However, results of both tests were the same with regard to the direction and significance of correlation coefficients, indicating that conclusions are not influenced by deviations from the assumptions of parametric correlation. Further on, only parametric correlation coefficients were reported.

Intersite comparison was investigated using one-way ANCOVA followed by post-hoc Tukey tests. Since we performed multiple tests on single null hypotheses (e.g., no difference between the study areas with regard to tissue variables), an adjustment of the probability of $\alpha^{\prime}$ - 

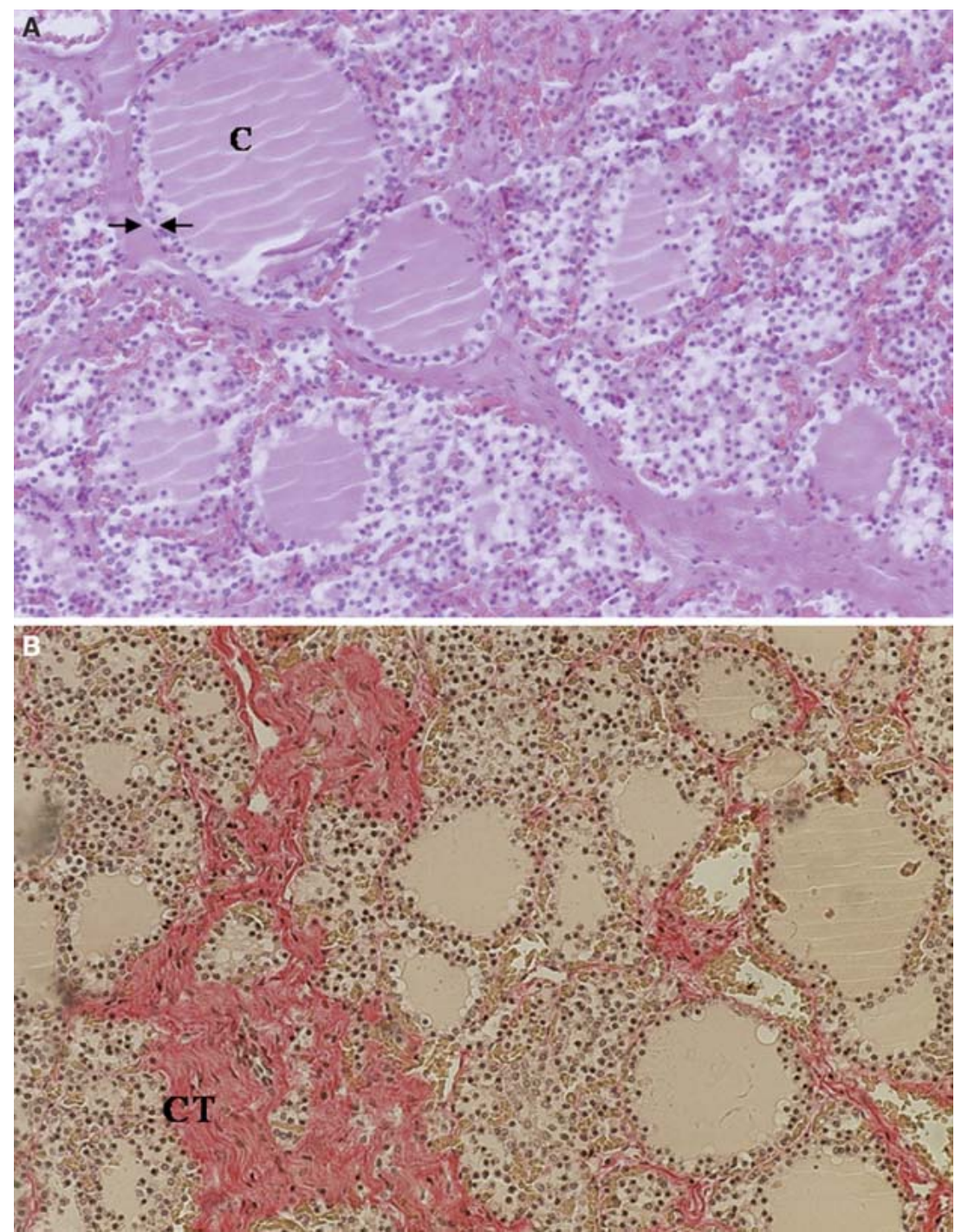

Fig. 2. Thyroid gland of a harbour porpoise from German waters. F: follicle. Colloid (C) is surrounded by thyroid epithelium (between the arrowheads). S: solid tissue. (A) Hematoxylin and eosin staining; (B) Van Giesson staining allowing the identification of the connective tissue (CT) in red. Magnification: X230 errors was required. $p$-values for the number of tests of the same nullhypothesis were thus corrected, applying the equation:

$$
p_{\mathrm{Ck}}=1-\left(1-\alpha^{\prime}\right)^{\mathrm{k}}
$$

derived from conversion of the Dunn-Šidák method (Sokal and Rohlf 1995) and in which $p_{\mathrm{Ck}}$ denotes the corrected $p$-value, $\alpha^{\prime}$ equals the originally derived $p$-value, and $k$ equals the number of tests. We calculated effect sizes applying the formula indicated in Bortz (1999).

\section{Results}

\section{Histological Investigations}

Three tissue compartments were distinguished in the thyroid gland: epithelium cells, follicles, and connective tissues (Figs. 2 and 3). Irregular or oval follicular lumens surrounded by follicular epithelial cells were seen in the parenchyma of the thyroid (Figs. 2 and 3). Narrow to large connective tissue strands can be found between the follicles (Fig. 2b). Connective tissue is typically rich in fibrous tissues and contained very few cells.

The tissue proportion median in the visual fields in the microscope ranged from 15 to $87.5 \%$ for the solid tissues, 2.5 to $37.5 \%$ for the follicles, and 2.5 to $62.5 \%$ for the connective tissues (Table 2).

The rabbit polyclonal antibody designed to react against human thyroglobulin cross-reacted positively in the thyroid of the harbour porpoises (Fig. 4). Thyroglobulin was positively detected in the lumen of the follicles either disseminated in the parenchyma or in the follicular epithelial cells.

Intersite comparisons revealed that harbour porpoises from Iceland displayed a lower proportion of connective tissue compared to porpoises from Germany (North and Baltic Seas) and Norway $(p<0.001)$ (Table 3$)$. The proportion of follicles $(\%)$ did not vary between locations $(p>0.1)$ (one-way ANCOVA, Table 3). Harbour porpoises from Iceland displayed also a higher number of small follicles compared to porpoises from other locations $(p<0.001)$. 


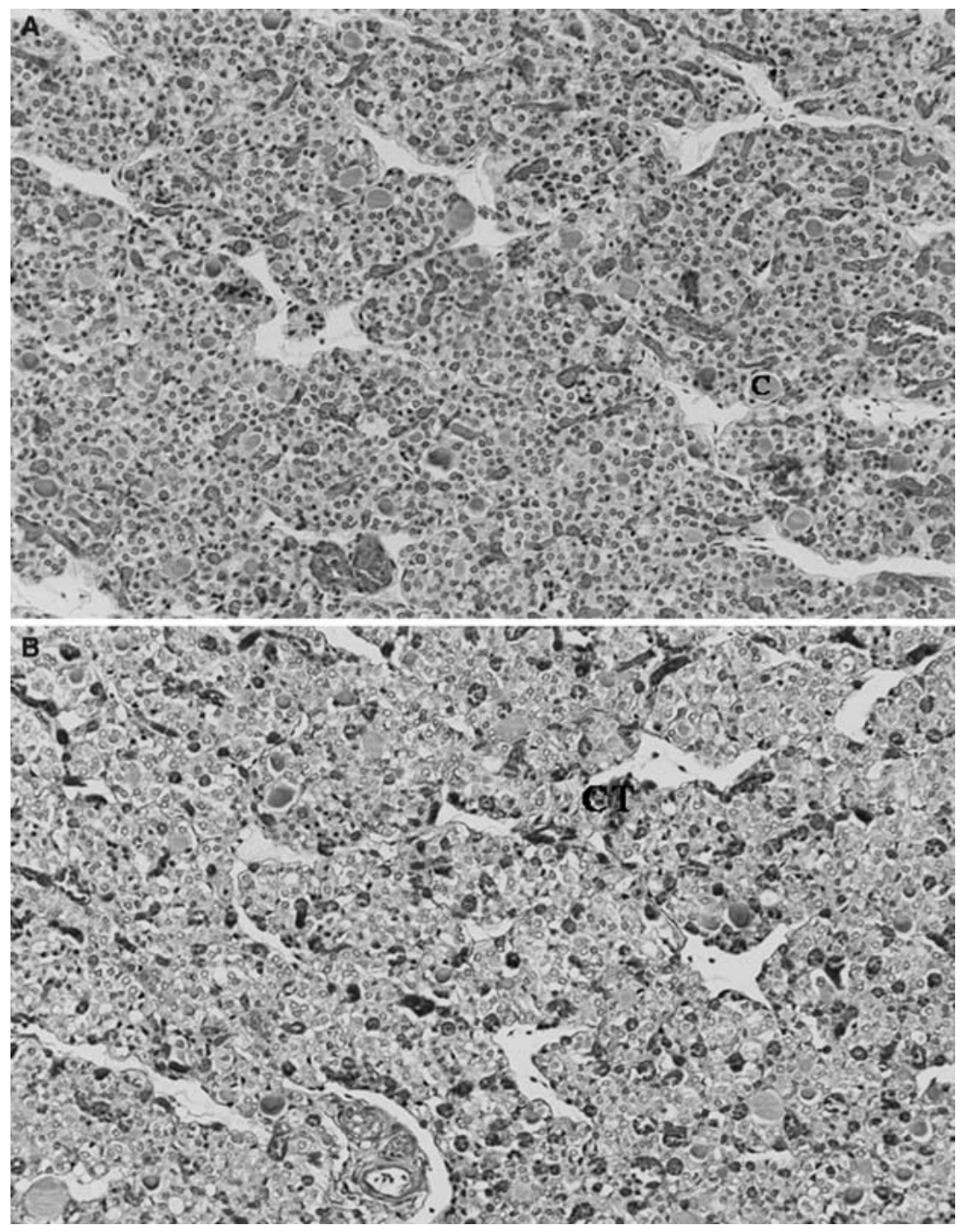

Fig. 3. Thyroid gland of a harbour porpoise from Icelandic waters. (A) Eosine coloration, C: colloid. (B) Van Giesson coloration allowing the identification of the connective tissue (CT) in red. Magnification: X230

Table 2. Morphometry of the thyroid gland and organochlorine concentrations ( $\mathrm{ng} \mathrm{g}^{-1}$ lipid) in the blubber of harbour porpoises from German and Danish Norwegian, and Icelandic coasts (Siebert et al. 2002; Thron et al. 2004)

\begin{tabular}{|c|c|c|c|c|}
\hline & $\begin{array}{l}\text { German coast } \\
\text { North Sea }(n=14)\end{array}$ & $\begin{array}{l}\text { German and Danish coasts } \\
\text { Baltic Sea }(n=17)\end{array}$ & $\begin{array}{l}\text { Icelandic coast } \\
(n=12)\end{array}$ & $\begin{array}{l}\text { Norwegian } \\
\text { coast }(n=13)\end{array}$ \\
\hline \multicolumn{5}{|l|}{ Tissue proportion } \\
\hline Solid tissue $(\%)$ & $59 \pm 14$ & $50 \pm 15$ & $91 \pm 0.05$ & $59 \pm 17$ \\
\hline Follicle $(\%)$ & $8 \pm 5$ & $12 \pm 15$ & $5 \pm 5$ & $6 \pm 9$ \\
\hline Connective tissue $(\%)$ & $33 \pm 15$ & $38 \pm 16$ & $3 \pm 1$ & $35 \pm 15$ \\
\hline \multicolumn{5}{|l|}{ Number of follicles } \\
\hline$<62.5 \mu \mathrm{m}$ & 42 & 36 & 353 & 33 \\
\hline Between 62.5 and $208 \mu \mathrm{m}$ & 99 & 56 & 65 & 19 \\
\hline$>208 \mu \mathrm{m}$ & 23 & 27 & 2 & 16 \\
\hline \multicolumn{5}{|l|}{ Pollutants } \\
\hline$\Sigma$ PCBs & $7664 \pm 5075$ & $8247 \pm 7949$ & $1550 \pm 1517$ & $4710 \pm 2861$ \\
\hline$\Sigma$ PBDE & $1081 \pm 1526$ & $219 \pm 219$ & $52 \pm 23$ & $481 \pm 320$ \\
\hline$\Sigma$ Toxaphene & $1051 \pm 1901$ & $445 \pm 504$ & $1187 \pm 625$ & $1525 \pm 493$ \\
\hline DDE & $1226 \pm 835$ & $1571 \pm 1587$ & $896 \pm 681$ & $1618 \pm 1122$ \\
\hline DDT & $255 \pm 252$ & $428 \pm 559$ & $226 \pm 140$ & $674 \pm 519$ \\
\hline
\end{tabular}

Data are given as mean (median) \pm standard deviation, range of concentrations (minimum-maximum); $n$ : number of samples; nd: not determined. 


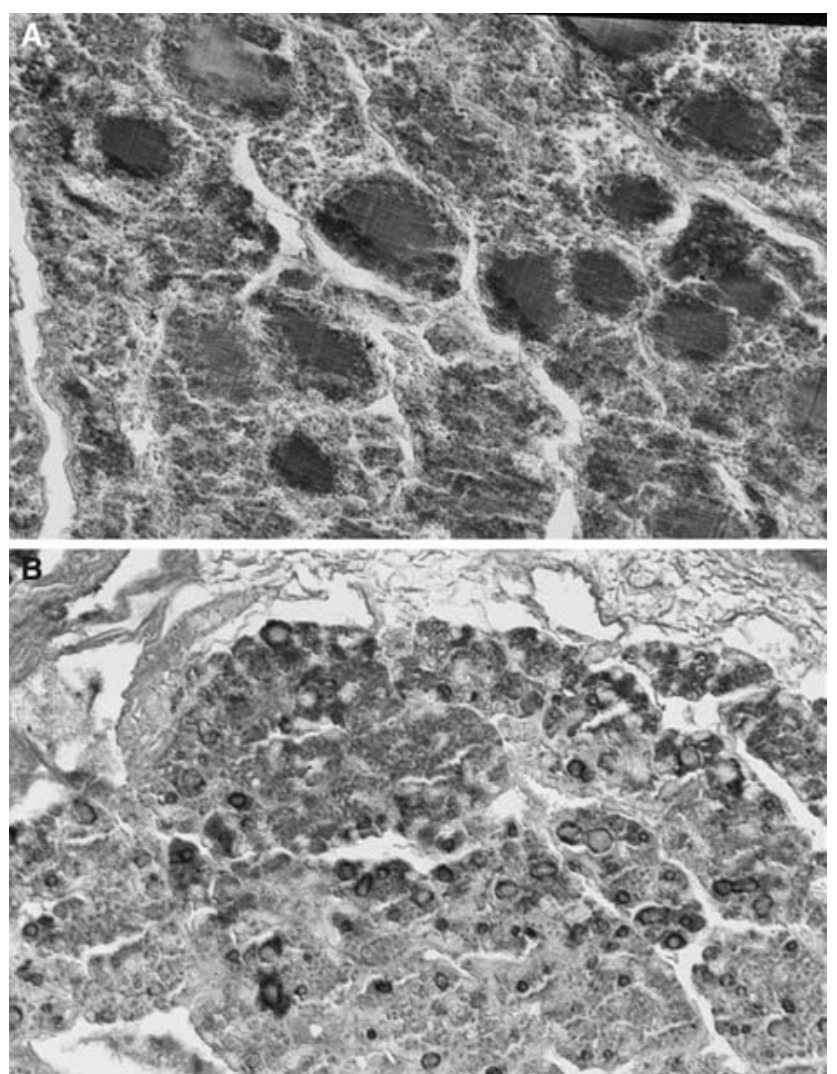

Fig. 4. Thyroglobulin-specific reaction in the thyroid of harbour porpoise from German (A) and Icelandic (B) waters. Magnification: $\mathrm{X} 230$

Table 3. Influence of sampling location (one-way ANCOVA results) on pollutants (components 1 and 2), thyroid tissue proportion, and the number of follicles

\begin{tabular}{|c|c|c|}
\hline & $\mathrm{F}$ & $p$ \\
\hline \multicolumn{3}{|l|}{ Pollutants } \\
\hline Component 1 & $\mathrm{~F}_{3,45}=3.9$ & $p=0.02$ \\
\hline Component 2 & $\mathrm{~F}_{3,45}=21.9$ & $p<0.0001$ \\
\hline \multicolumn{3}{|l|}{ Tissue proportion (\%) } \\
\hline Connective tissue $(\%)$ & $\mathrm{F}_{3,50}=13.2$ & $p<0.0001$ \\
\hline Follicle tissue $(\%)$ & $\mathrm{F}_{3,50}=1.8$ & $p=0.6$ \\
\hline \multicolumn{3}{|l|}{ Number of follicles } \\
\hline$<62.5 \mu \mathrm{m}$ & $\mathrm{F}_{3,50}=11.1$ & $p<0.0001$ \\
\hline Between 62.5 and $208 \mu \mathrm{m}$ & $\mathrm{F}_{3}, 50=2.3$ & $p=0.4$ \\
\hline$>208 \mu \mathrm{m}$ & $\mathrm{F}_{3,50}=3.7$ & $p=0.09$ \\
\hline
\end{tabular}

$p$ indicated as $p_{\mathrm{ck}}$-values.

\section{Relationship with Pollutants}

PCBs, PBDE, toxaphene, DDE, and DDT results (Table 2) were extracted from a larger study presented elsewhere (Siebert et al. 2002; Thron et al. 2004).

A correlation-based principal component analysis (PCA) revealed two principal components that explained $85.9 \%$ of the total variance (Table 4). The variables PCB, PBDE, DDT, and DDE compounds loaded highest on PC1 (all loadings positive
Table 4. Summary of the principal component analysis results for the two first components (PCs)

\begin{tabular}{lcc}
\hline & Component 1 & Component 2 \\
\hline PCBs $(\log )$ & $\mathbf{0 . 7 3}$ & -0.65 \\
PBDE $(\log )$ & $\mathbf{0 . 8 0}$ & -0.16 \\
Toxaphene $(\log )$ & 0.65 & $\mathbf{0 . 7 2}$ \\
DDE $(\log )$ & $\mathbf{0 . 9 4}$ & -0.07 \\
DDT $(\log )$ & $\mathbf{0 . 8 9}$ & 0.23 \\
Variance explained (cumulative) & $\mathbf{6 5 . 2} \%$ & $\mathbf{8 5 . 9} \%$ \\
\hline
\end{tabular}

The boldface values refer to the main correlation between the PCs and the variables.

and all at least 0.73 ) whereas toxaphene compound loaded most on PC2 (loading: 0.72).

Multiple regressions of these two principal components with tissue proportions and number of follicles revealed a significant relationship between pollutants and thyroid lesions (Table 5). PC1 (PCBs, PBDE, DDT, DDE) was negatively correlated to the proportion of follicle tissue $(\%)$ and to the number of small and middle-size follicles. PC1 was also positively correlated to the proportion of connective tissue (Table 5). PC2 was negatively correlated to the proportion of connective tissue and to the number of large follicles. PC2 (mainly toxaphene) was also positively correlated to the number of small follicles.

The response of the vector "connective tissue" co-varied strongly with the levels of PCBs concentration in the blubber (Fig. 5). This bi-plot, retaining all individuals, is based on Pearson's correlation coefficients between percentages of tissues $(\%$ of solid tissue, $\%$ of follicular tissue, and $\%$ of connective tissue) as well as numbers of small, medium, and large follicles, on the one hand, and principal components (PC1), on the other hand.

\section{Discussion}

The present study revealed strong variability in ultrastructural morphology of the harbour porpoise thyroid. Harbour porpoises from the German coast (North and Baltic Seas) and Norwegian coasts displayed a higher proportion of connective tissue than porpoises from Icelandic coasts. Furthermore, porpoises caught along the Icelandic coasts had a higher proportion of solid tissue (parenchyma) and smaller-size follicles. Porpoises collected along the German and Norwegian coasts (North and Baltic Seas) displayed a percentage of connective tissue up to $60 \%$ revealing a severe dysfunction of their thyroid gland. In the thyroid and other tissues, the progressive accumulation of connective tissue, a complex and dynamic process termed fibrosis, represents an event following a repeated or chronic insult of sufficient intensity to trigger a "wound healing"-like reaction (Banks 1986; Jubb et al. 1993). The underlying mechanisms leading to thyroid fibrosis are unclear but would result from tissue damage and disturbed inflammatory reaction (Contempre et al. 1996). The factors involved in the thyroid fibrosis process include follicular atrophy, thyroiditis, radiation, carcinoma, selenium deficiency, and chronic exposure to organic contaminants (Gemma et al. 
Table 5. Multiple regression results for the relationship between the two components resulting from PCA and the proportion of tissue in the thyroid and number of follicles

\begin{tabular}{|c|c|c|c|c|}
\hline & \multicolumn{2}{|c|}{ Component 1} & \multicolumn{2}{|c|}{ Component 2} \\
\hline & $\mathrm{t}$-value & $p$-value & t-value & $p$-value \\
\hline \multicolumn{5}{|l|}{ Tissue proportion $(\%)$} \\
\hline Follicles & -3.3 & 0.02 & -2.9 & 0.06 \\
\hline Connective tissue & 2.7 & 0.01 & -3.5 & 0.001 \\
\hline \multicolumn{5}{|l|}{ Number of follicles } \\
\hline$<62.5 \mu \mathrm{m}$ & -3.1 & 0.003 & 3.3 & 0.002 \\
\hline Between 62.5 and $208 \mu \mathrm{m}$ & -3.2 & 0.002 & -1.3 & 0.2 \\
\hline$>208 \mu \mathrm{m}$ & -0.6 & 0.5 & -3.6 & 0.001 \\
\hline
\end{tabular}

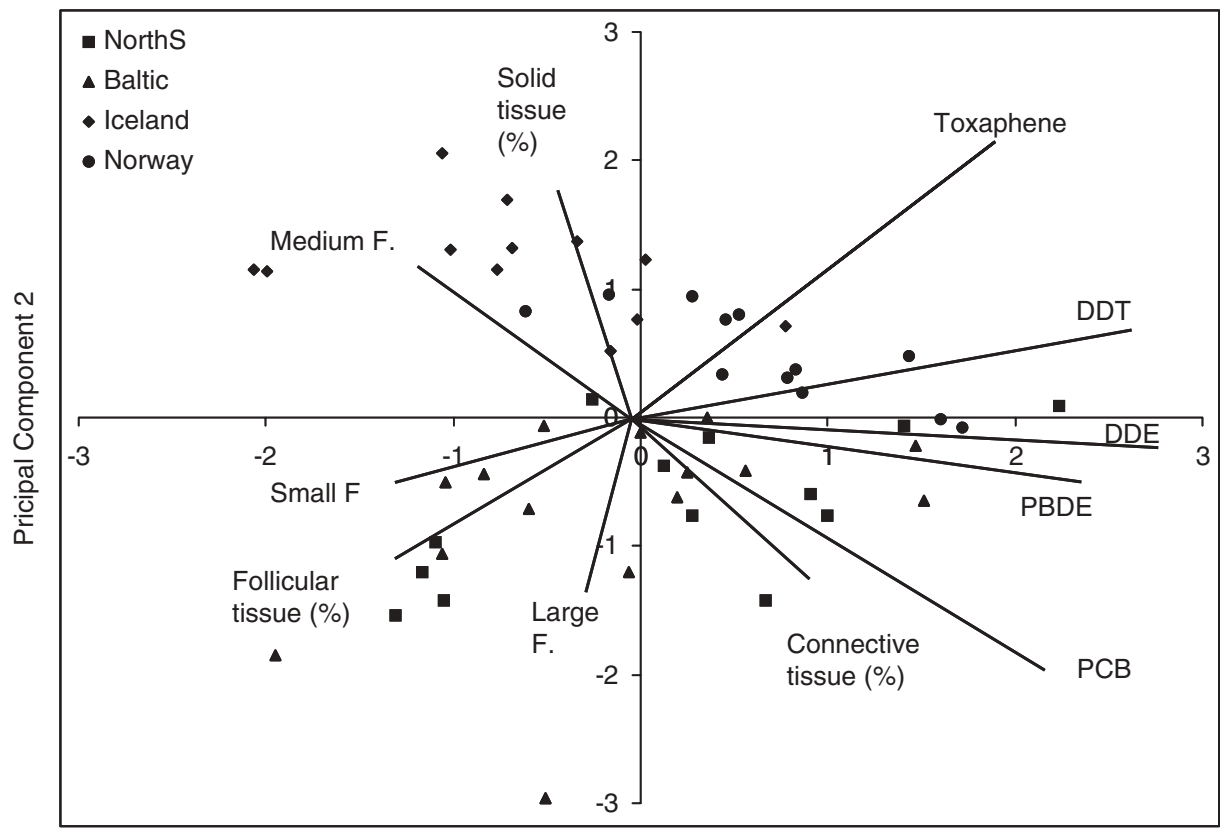

Principal Component 1
Fig. 5. Co-variation bi-plot. Individuals are shown as points in the PC1-PC2 plane. 25 Contaminant vector (log-transformed concentrations) and thyroid factors are given as vectors representing the Pearson's correlations with the 1st and 2nd PC
2001; Hanson et al. 1983; Jubb et al. 1993; Schumacher et al. 1993; Contempre et al. 1996). Replacement of thyroid follicles tissue by connective tissue results in severe impairment of the thyroid function.

Our results pointed out a relationship between $\mathrm{PCB}$, $\mathrm{PBDE}$, DDE, and DDT compounds and histological characteristics of the harbour porpoise thyroids. The increase of connective tissues in this tissue is mainly correlated to the increase of component 1 (PCBs, PBDE, DDE, DDT concentrations in the blubber). Furthermore, the response of the vector "connective tissue" co-varied strongly with the levels of PCB illustrated by the small angles between the two vectors (Fig. 5).

Harbour porpoises from Iceland displayed far lower PCB, PBDE, DDE, and DDT concentrations in the blubber than porpoises collected along the German or Norwegian coasts while toxaphene concentration was higher in porpoises from Iceland (Thron et al. 2004).

Previous studies have demonstrated that these environmental contaminants can alter various aspects of thyroid function in several vertebrate species (e.g., Brouwer et al. 1989; Byrne et al. 1987; Chiba et al. 2001; Collins et al. 1977;
Collins and Capen 1980a, 1980b, 1980c; Desaulniers et al. 1999; Langer et al. 1998; Schumacher et al. 1993; Sepkovic and Byme 1984; Tryponas et al. 1984). The cellular mechanisms involved in thyroid pathology are poorly known. Generally, endocrine disrupter compounds act at multiple sites via multiple mechanisms of action. The generally accepted paradigm for receptor-mediated response includes interactions of chemicals with hormonal receptor systems and transportbinding proteins (Wright and Welbourn 2002). Several PCB congeners are metabolized by the cytochrome P-450 enzymes and form hydroxymetabolites that can interfere with the blood transport system of T4 (thyroxin-transthyretin) (Brouwer and Van Den Berg 1986; Brouwer et al. 1989, 1998). By exhibiting structural similarities with T4, some OC hydroxymetabolites compete for the binding site of $\mathrm{T} 4$ on its transport protein (TTR), resulting in a loss of free $\mathrm{T} 4$ from the circulation (Brouwer and Van Den Berg 1986; Brouwer 1989; Brouwer et al. 1998).

Thyroid hormone levels in the blood of grey seals during their first year of life were significantly correlated to total PBDEs in the blubber (Hall et al. 2003). Seals with higher 
blubber PBDEs had relatively significantly higher blood TT4 and TT3 concentrations (Hall et al. 2003).

Much of the toxicological work on laboratory animals has reported a negative correlation between organohalogens and serum levels of hormones. Experimental PCB exposure on rats revealed low $\mathrm{T} 4$ levels in the serum combined to hypertrophy of follicular cells, extensive dilation of rough endoplasmic reticulum, only occasional colloid droplets, and limited lysosome-colloid droplets interaction (Collins and Capen 1980c; Kazka et al. 1978). PCBs depress plasma levels of T4 in seals and in polar bears (Braathen et al. 2004; Brouwer et al. 1989; Reijnders 1986). Seals fed fish from the Wadden Sea (highlevel PCB contamination) had significantly lower concentrations of plasma retinol, total (TT4) and free thyroxin (FT4), and triiodothyronin (TT3) as compared to seals fed fish from the northeast Atlantic (low-level PCB contamination) (Brouwer et al. 1989). Concentrations of PCBs in serum lipids were negatively correlated with serum vitamin $\mathrm{A}$ and $\mathrm{T} 3$ in the juvenile California sea lions, potentially reflecting PCB-related toxicity (Debier et al. 2005). Environmental contaminants acting as endocrine disrupters upset the thyroid hormone balance of mammals (Brouwer et al. 1989; Hall et al. 1998, 2003; Debier et al. 2005) and may produce histological detectable abnormalities such as colloid depletion and fibrosis in their thyroid, resulting in impairment of thyroid function (Schumacher et al. 1993; Gregory and Cyr 2003).

\section{Conclusions}

Although the relationships found between organohalogen burdens and thyroid dysfunction is not evidence of a direct cause-effect association, we cannot reject the hypothesis that contaminants such as PCBs, PBDEs, DDT, and DDE may interfere with the harbour porpoise thyroid functions leading to severe interfollicular fibrosis. Furthermore, the influence of these findings on the endocrine and health status of the harbour porpoises have to be clarified.

Acknowledgments. This work was funded by the Environmental Research Plan of the German Ministry of Environment (Federal Agency of Environment; F+E-Vorhaben 29965 221/0). Thanks to R. Mundry for statistical analyses. Krishna Das received grants from the Marie-Curie Fellowship (EVK3-CT-2002-50009) and from FNRS (Fonds National pour la Recherche Scientifique). This paper is a MARE publication no. 074 .

\section{References}

Aguilar A, Borrell A (1995) Pollution and harbour porpoises in the eastern North Atlantic: a review. In: Bjørge A, Donovan GP (eds) Biology of the Phocoenids. Report of the International Whaling Commission Special Issue 16:231-242

Banks WJ (1986) Applied Veterinary histology. 2nd ed. Williams and Wilkins, Baltimore

Baumgärtner W, Örvell C, Reinacher M (1989) Naturally occurring canine distemper virus encephalitis: distribution and expression of viral polypeptides in nervous tissues. Acta Neuropathol 78:504 512
Benke H, Siebert U, Lick R, Bandomir B, Weiss R (1998) The current status of harbour porpoises (Phocoena phocoena) in German waters. Arch Fish Mar Res 46:97-123

Bergman A (1999) Health condition of the Baltic grey seal (Halichoerus grypus) during two decades. Gynaecological health improvement but increased prevalence of colonic ulcers. Acta Pathol Microbiol Immunol Scand 107:270-282

Bergman A, Bignert A, Olsson M (2002) Pathology in Baltic grey seals (Halichoerus grypus) in relation to environmental disruptors. In: Vos JG, Bossart G, Fournier M, O'Shea T (eds) Toxicology of marine mammals. Taylor \& Francis, Washington, DC, pp 507-533

Bergman A, Olsson M (1985) Pathology of Baltic grey seals and ringed seal females with special reference to adrenocortical hyperplasia: is environmental pollution the cause of a widely distributed disease syndrome? Finnish Game Res 44:47-62

Bortz J (1999) Statistik für Sozialwissenschaftler. Springer, Berlin

Braathen M, Derocher AE, Wiig Ø, Sørmo EG, Lie E, Skaare JU, Jenssen BM (2004) Relationships between PCBs and thyroid hormones and retinol in female and male polar bears. Environ Health Perspect 111:826-833

Brouwer A, Van Den Berg KJ (1986) Binding of a metabolite of $3,4,3^{\prime}, 4$,-tetrachlorobiphenyl to transthyretin reduces serum vitamin A transport by inhibiting the formation of the protein complex carrying both retinol and thyroxin. Toxicol Appl Pharmacol 85:301-312

Brouwer A, Reijnders PJH, Koeman JH (1989) Polychlorinated biphenyls (PCB)-contaminated fish induces vitamin A and thyroid hormone deficiency in the common seal (Phoca vitulina). Aquatic Toxicol 15:99-106

Brouwer A, Morse DC, Lans MC, Schuur AG, Murk AJ, KlassonWehler E, Begman A, Visser TJ (1998) Interactions of persistent environmental organohalogénés with the thyroid hormone system: mechanism and possible consequences for animal and human health. Toxicol Ind Health 14:59-84

Brouwer A, Longnecker MP, Birnbaum LS, Cogliano J, Kostyniac P, Moore J, Schantz S, Winneke G (1999) Characterization of potential endocrine-related health effects at low-dose levels of exposure to PCBs. Environ Health Perspect 107(Suppl 4):639649

Bruhn R, Kannan N, Petrick G, Schulz-Bull DE, Duinker JC (1995) $\mathrm{CB}$ pattern in the harbour porpoise: bioaccumulation, metabolism and evidence for cytochrome P450 IIB activity. Chemosphere 31:3721-3732

Bruhn R, Kannan N, Petrick G, Schulz-Bull DE, Duinker JC (1999) Persistent chlorinated organic contaminants in harbour porpoises from the North Sea, the Baltic Sea and Arctic waters. Sci Total Environ 237/238:351-361

Byrne JJ, Carbone JP, Hanson EA (1987) Hypothyroidism and abnormalities in the kinetics of thyroid hormone metabolism in rats treated chronically with polychlorinated biphenyl and polybrominated biphenyl. Endocrinology 121:520-527

Chiba I, Sakakibara A, Goto Y, Isono T, Yamamoto Y, Iwata H, Tanabe S, Shimazaki K, Akahori F, Kazusaka A, Fujita S (2001) Negative correlation between plasma thyroid hormone levels and chlorinated hydrocarbon levels accumulated in seals from the coast of Hokkaido, Japan. Environ Toxicol Chem 20:1092-1097

Colborn T (2002) Clues from wildlife to create an assay for thyroid system disruption. Environ Health Perspect 110:363-367

Collins WT, Capen CC (1980a) Biliary excretion of 125I-thyroxine and fine structural alterations in the thyroid glands of Gunn rats fed polychlorinated biphenyls (PCBs). Lab Invest 43:158-164

Collins WT, Capen CC (1980b) Fine structural lesions and hormones alterations in thyroid glands of perinatal rats exposed in utero and by milk to polychlorinated biphenyls. Am J Pathol 99:125-142

Collins WT, Capen CC (1980c) Ultrastructural and functional alterations of the rat thyroid gland produced by polychlorinated bi- 
phenyls compared with iodide excess and deficiency, and thyotropin and thyroxine administration. Virchows Arch B Cell Pathol 33:213-231

Collins WT, Capen CC, Kaska L, Carter C, Dailey RE (1977) Effects of polychlorinated biphenyl (PCB) on the thyroid gland of rats. Ultrastructural and biochemical investigations. Am J Pathol 89:119-130

Contempre B, Le Moine O, Dumont JE, Denef JF, Many MC (1996) Selenium deficiency and thyroif fibrosis. A key role for macrophages and transforming growth factor $\beta$ (TGF- $\beta$ ). Mol Cell Endocrinol 124:7-15

Das K, Debacker V, Pillet S, Bouquegneau JM (2003) Heavy metals in marine mammals. In: Vos JG, Bossart G, Fournier M, O'Shea T (eds) Toxicology of marine mammals. Taylor \& Francis, Washington, DC, pp 135-167

Das K, Siebert U, Fontaine M, Jauniaux T, Holsbeek L, Bouquegneau JM (2004) Ecological and pathological factors related to trace metal concentrations in harbour porpoises Phocoena phocoena from the North Sea and adjacent areas. Mar Ecol Prog 281:283295

Debier C, Ylitalo GM, Weise M, Gulland F, Costa DP, Le Boeuf BJ, de Tillesse T, Larondelle Y (2005) PCBs and DDT in the serum of juvenile California sea lions: associations with vitamins A and E and thyroid hormones. Environ Pollut 134:323-332

Desaulniers D, Leingartner K, Wade M, Fintelman E, Yagminas A, Foster WG (1999) Effects of acute exposure to PCBs 126 and 153 on anterior pituitary and thyroid hormones and FSH isoforms in adult Sprague Dawley male rats. Toxicol Sci 47:158-169

Gabriel KR (1971) The bi-plot graphic display of matrices with application to principal component analysis. Biometrika 58:453467

Gemma R, Miura K, Mikami T, Natsume H, Nishiyama K, Nakamura $\mathrm{H}$ (2001) Histological changes of thyroid tissues in patients with liver cirrhosis. Endocr J 48:535-542

Gregory M, Cyr DG (2003) Effects of environmental contaminants on the endocrine system of marine mammals. In: Vos JG, Bossart G, Fournier M, O'Shea T (eds) Toxicology of marine mammals. Taylor \& Francis, Washington, DC, pp 66-81

Hall AJ, Green NJL, Jones KC, Pomeroy PP, Harwood J (1998) Thyroid hormones as biomarkers in grey seals. Mar Pollut Bull 36:424-428

Hall AJ, Kalantzi OI, Thomas GO (2003) Polybrominated diphenyl ethers (PBDEs) in grey seals during their first year of life: are they thyroid hormone endocrine disrupters? Environ Pollut 126:29-37

Hammond PS, Berggren P, Benke H, Borchers DL, Buckland ST, Collet A, Heide-Jørgensen MP, Heimlich S, Hiby AR, Leopold MF, Øien N (2002) Abundance of harbour porpoise and other cetaceans in the North Sea and adjacent waters. J Applied Ecol 39:361-376

Hanson GA, Komorowski RA, Cerletty JM, Wilson SD (1983) Thyroid gland morphology in young adults: normal subjects versus those prior low-dose neck irradiation in childhood. Surgery 94:984-988

Jepson PD, Bennet PM, Allchin CR, Law RJ, Kuiken T, Baker JR, Rogan E, Kirkwood JK (1999) Investigating potential associations between chronic exposure to polychlorinated biphenyls and infectious disease mortality in harbour porpoises from England and Wales. Sci Total Environ 243/244:339-348

Jepson PD, Bennet PM, Deaville R, Allchin CR, Baker JR, Law RJ (2005) Relationship between polychlorinated biphenyls and health status in harbour porpoises (Phocoena phocoena) stranded in the United Kingdom. Environ Toxicol Chem 24:238-248

Jubb KVF, Kennedy PC, Palmer N (1993) Pathology of domestic animals, Vol. 3. Academic Press, San Diego

Kazka L, Collins WT, Capen CC, Garthoff LH, Friedman L (1978) Comparative toxicity of polychlorinated biphenyls and polybro- minated biphenyls in the rat thyroid gland. Light and electron microscopic alterations after subacute dietary exposure. J Environ Pathol Toxicol 1:587-599

Kleivane L, Skaare JU, Bjorge A, de Ruiter E, Reijnders PJH (1995) Organochlorine pesticide residue and PCBs in harbour porpoises (Phocoena phocoena) incidentally caught in Scandinavian waters. Environ Pollut 89:137-146

Langer P, Tajtakova M, Fodor G, Kocan A, Bohov P, Michalek J, Kreze A (1998) Increased thyroid volume and prevalence of thyroid disorders in an area heavily polluted by polychlorinated biphenyls. Eur J Endocrinol 139:402-406

Lockyer C (1995) A review of factors involved in zonation in Odontocetes teeth, and an investigation of the likely impact of environmental factors and major life events on harbour porpoise tooth structure. In: Bjorge A, Donovan GP (eds) Biology of the Phocoenids. International Whaling Commission, Cambridge, pp 511-529

McGregor PK (1992) Quantifying responses to playback: one, many, or composite multivariate measures? In: McGregor PK (ed) Playback and Studies of Animal communication. Plenum Press, New York

McNabb FMA (1992) Thyroid hormones. Prentice Hall, Englewood Cliffs. NJ

O'Hara TM, Becker PR (2003) Persistent organic contaminants in Arctic marine mammals. In: Vos JG, Bossart G, Fournier M, $\mathrm{O}^{\prime}$ Shea $\mathrm{T}$ (eds) Toxicology of marine mammals. Taylor \& Francis, Washington, DC, pp 168-205

O'Shea TJ, Tanabe S (2003) Persistent ocean contaminants and marine mammals: a retrospective overview. In: Vos JG, Bossart G, Fournier M, O'Shea T (eds) Toxicology of marine mammals. Taylor \& Francis, Washington, DC, pp 99-134

Read AJ (2002) Porpoises: Overview. In: Perrin WE, Würsig B, Thewissen JGM (eds) Encyclopedia of marine mammals. Academic Press, San Diego, pp 982-985

Reijnders PJH (1986) Reproductive failure in common seals feeding on fish from polluted coastal waters. Nature 324:456-457

Reijnders PJH, Aguilar A (2002) Pollution and marine mammals. In: Perrin WE, Würsig B, Thewissen JGM (eds) Encyclopedia of marine mammals. Academic Press, San Diego, pp 948-957

Schumacher Z, Zahler S, Horny HP, Heidemann G, Skrinisson K, Welsch U (1993) Histological investigation on the thyroid glands of marine mammals (Phoca vitulina, Phocoena phocoena) and the possible implications of marine pollution. J Wildlife Dis 29:103-108

Sepkovic DW, Byme JJ (1984) Kinetic parameters of $\mathrm{L}^{-(125)}$-triiodothyronine degradation in rats pretreated with polyhalogenated biphenyls. Food Chem Toxicol 22:743-747

Sher ES, Xu XM, Adams PM, Craft CM, Stein SA (1998) The effects of thyroid hormone level and action in developing brain: are these targets for the action of polychlorinated biphenyls and dioxins? Toxicol Ind Health 14:121-158

Siebert U, Wünschmann A, Weiss R, Frank H, Benke H, Frese K (2001) Post-mortem findings in harbour porpoises (Phocoena phocoena) from the German North and Baltic Seas. J Comp Pathol 124:102-114

Siebert U, Vossen A, Baumgärtner W, Müller G, Beineke A, McLachlan M, Bruhn R, Thron K (2002) Investigations of the influence of pollutants on the endocrine and immune system of harbour porpoises in the German North and Baltic Seas. Forschungbericht 29965 221/01, Federal Agency of Environment; Berlin

Sokal RR, Rohlf FJ (1995) Biometry: The principles and practice of statistics in biological research. Freeman \& Company, New York

Thron KU, Bruhn R, McLachlan MS (2004) The influence of age, sex, body-condition and regions on the levels of PBDEs and 
toxaphene in harbour porpoises from European waters. Fresenius Environ Bull 13:146-155

Tryponas L, Truelove J, Zawidzka Z, Wong J, Mes J, Charbonneau S, Grant DL, Campbell JS (1984) Polychlorinated biphenyl (PCB) toxicity in adult cynomolgus monkeys (Macaca fascicularis): a pilot study. Toxicol Pathol 12:10-25

Woldstad S, Jensen BM (1999) Thyroid hormones in grey seal pups (Halichoerus grypus). Comp Biochem Physiol Part A 122:157-162
Wright DA, Welbourn P (2002) Organic compounds. In: Wright DA, Welbourn P (eds) Environmental toxicology. Environmental Chemistry series 11. Cambridge University Press, Cambridge, pp 249-348

Zhou T, John-Alder HB, Weis JS, Weis P (2000) Endocrine disruption: thyroid dysfunction in mummichogs (Fundulus heteroclitus) from a polluted habitat. Mar Environ Res 50:393397 